\title{
Implementasi Metode Experiential Learning dalam Menumbuhkan Perilaku Kesehatan dan Keselamatan Anak Usia Dini
}

\author{
Ni Made Ayu Suryaningsih', I Made Elia Cahaya2 ${ }^{2}$, dan Christiani Endah Poerwati ${ }^{3}$ \\ Pendidikan Guru Pendidikan Anak Usia Dini, Universitas Dhyana Pura, Bali \\ DOI: $\underline{10.31004 / \text { obsesi.v4i1.317 }}$
}

\begin{abstract}
Abstrak
Penelitian ini bertujuan untuk menumbuhkan perilaku kesehatan dan keselamatan anak usia dini. Jenis penelitian ini adalah penelitian tindakan (action research) dengan prosedur empat-tahap, yaitu: 1) Tahap perencanaan, 2) Tahap pengambilan tindakan, 3) Tahap pengembangan, 4) Tahap refleksi. Penelitian akan dilaksanakan dalam dua siklus. Metode pengumpulan data yang digunakan dalam penelitian ini yakni melalui observasi. Proses pengumpulan data melalui teknik observasi ini menggunakan panduan rubrik untuk merekam data mengenai perilaku kesehatan dan keselamatan anak selama mengikuti proses pembelajaran. Data yang terkumpul selanjutnya dianalisis secara deskriptif. Hasil penelitian menunjukan persentase penguasaan perilaku kesehatan dan keselamatan anak usia dini pada observasi awal sebesar 28,58\%. Melalui penerapan metode Experiential Learning, perilaku kesehatan dan keselamatan anak usia dini mengalami peningkatan pada siklus I menjadi $66,67 \%$ dan siklus II menjadi $90,48 \%$. Sehingga dapat disimpulkan bahwa penerapan metode Experiential Learning, dapat menumbuhkan perilaku kesehatan dan keselamatan pada anak usia dini
\end{abstract}

Kata Kunci : anak usia dini, perilaku kesehatan dan keselamatan, metode experiential learning

\begin{abstract}
This study aims to foster early childhood health and safety behaviors. This type of research is an action research with a four-stage procedure, namely: 1) The planning stage, 2) The action taking stage, 3) The development stage, 4) The reflection phase. The research will be carried out in two cycles. Data collection methods used in this study are through observation. The process of collecting data through this observation technique uses a rubric guide to record data about children's health and safety behaviors during the learning process. The collected data is then analyzed descriptively. The results showed the percentage of mastery of health behaviors and early childhood safety at initial observation amounted to $28.58 \%$. Through the application of the Experiential Learning method, early childhood health and safety behaviors have increased in the first cycle to $66.67 \%$ and in the second cycle to $90.48 \%$. So it can be concluded that the application of Experiential Learning method, can foster health and safety behavior in early childhood
\end{abstract}

Keywords: early childhood, health and safety behavior, Experiential Learning method

Copyright (c) 2019 Ni Made Ayu Suryaningsih, I Made Elia Cahaya, Christiani Endah Poerwati $\triangle$ Corresponding author:

Email Address : suryaningsih@undhirabali.ac.id (Br. Pegongan, Abiansemal, Badung, Bali)

Received 26 October 2019, Aceepted 1 November 2019, Published 5 November 2019 


\section{PENDAHULUAN}

Anak usia dini merupakan aset penting bagi masa depan suatu bangsa. Ditangan mereka kelak akan ditentukan arah kebijakan suatu bangsa. Keberhasilan ataupun kegagalan usaha mendidik mereka akan memiliki pengaruh yang besar baik bagi mereka sendiri ataupun bagi bangsa dan negara. Untuk itu, usaha membentuk generasi muda yang cemerlang harus menjadi tanggung jawab segala pihak.

Pendidikan Anak Usia Dini merupakan suatu program yang berperan penting dalam mempersiapkan dan menjamin pertumbuhan dan perkembangan anak. Dalam UU No. 20 tahun 2003 disebutkan bahwa pendidikan anak usia dini adalah suatu upaya pembinaan yang ditujukan kepada anak sejak lahir sampai dengan usia 6 tahun yang dilakukan melalui pemberian rangsangan pendidikan untuk membantu pertumbuhan dan perkembangan jasmani dan rohani agar anak memiliki kesiapan dalam memasuki pendidikan lebih lanjut (Indonesia, 2006). Pendidikan anak usia dini diselenggarakan dalam peletakan dasar ke arah pertumbuhan dan 6 perkembangan, yaitu : perkembangan moral dan agama, perkembangan fisik (koordinasi motorik halus dan kasar), kecerdasan/kognitif (daya pikir, daya cipta), sosio emosional (sikap dan emosi), bahasa dan komunikasi serta seni. Perlakuan pendidikan yang diberikan pada usia dini diyakini akan terpateri kuat di dalam hati dan pikiran anak yang jernih (Suyanto, 2012).

Tujuan Utama Pendidikan anak usia dini yakni memfasilitasi pertumbuhan dan perkembangan anak sedini mungkin yang meliputi aspek-aspek fisik, psikis dan sosial secara menyeluruh, yang merupakan hak anak (Yufiarti, 2014). Kegiatan tersebut memiliki makna yang sama dengan melakukan suatu pembangunan kualitas bangsa. Pembangunan kualitas anak usia dini tidak jauh berbeda dengan pembangunan sumber daya manusia. Yakni dengan memperhatikan kebutuhan anak serta menjamin perlindungan dan pemerolehan hak-hak anak.

Dalam Undang-Undang Republik Indonesia Nomor 35 Tahun 2014 Tentang Perlindungan Anak pada Pasal 72 nomor (1) Disebutkan bahwa Masyarakat berperan serta dalam Perlindungan Anak, baik secara perseorangan maupun kelompok (Setyawan, 2014). Pada nomor (2) menyebutkan Peran Masyarakat sebagaimana dimaksud pada ayat (1) dilakukan oleh orang perseorangan, lembaga perlindungan anak, lembaga kesejahteraan sosial, organisasi kemasyarakatan, lembaga pendidikan, media massa, dan dunia usaha. Kemudian pada nomor (4) menyebutkan bahwa Peran organisasi kemasyarakatan dan lembaga pendidikan sebagaimana dimaksud pada ayat (2) dilakukan dengan cara mengambil langkah yang diperlukan sesuai tugas, fungsi, dan kewenangan masing-masing untuk membantu penyelenggaraan Perlindungan Anak. Berdasarkan paparan UndangUndang Republik Indonesia Nomor 35 Tahun 2014 pada pasal 72 nomor 1, 2 dan 4 tersebut, dapat kita pahami mengenai usaha perlindungan anak dilakukan pula oleh lembaga pendidikan dengan cara mengambil langkah yang diperlukan sesuai tugas, fungsi, dan kewenangan masing-masing untuk membantu penyelenggaraan perlindungan anak.

Sedangkan pada Peraturan Menteri Kesehatan Republik Indonesia Nomor 25 Tahun 2014 Tentang Upaya Kesehatan Anak pada pasal 1 nomor 9, disebutkan bahwa Upaya Kesehatan Anak adalah setiap kegiatan dan/atau serangkaian kegiatan yang dilakukan secara terpadu, terintegrasi dan berkesinambungan untuk memelihara dan meningkatkan derajat kesehatan anak dalam bentuk pencegahan penyakit, pengobatan penyakit, dan pemulihan kesehatan oleh Pemerintah, pemerintah daerah dan/atau masyarakat. Ditambah lagi penjelasan pada pasal yang berbunyi Ruang lingkup pengaturan dalam Peraturan Menteri ini, meliputi Upaya Kesehatan Anak dengan pendekatan pemeliharaan peningkatan kesehatan (promotif), pencegahan penyakit (preventif), penyembuhan penyakit (kuratif), dan pemulihan penyakit (rehabilitatif) yang dilaksanakan secara menyeluruh terpadu dan berkesinambungan (Kemenkes, 2014).

Peran lembaga pendidikan dalam usaha meningkatkan kesehatan anak, dapat berupa kegiatan peningkatan kesehatan (promotif), pencegahan penyakit (preventif), penyembuhan 188 | Jurnal Obsesi : Jurnal Pendidikan Anak Usia Dini, 4(1), 2020 
penyakit (kuratif), maupun pemulihan penyakit (rehabilitatif) yang dilaksanakan secara menyeluruh terpadu dan berkesinambungan. Upaya pemeliharaan kesehatan anak selama berada di satuan PAUD, tidak hanya dilakukan oleh pendidik saja, melainkan seluruh masyarakat sekolah, tidak terkecuali peran anak itu sendiri. Orang-orang menghabiskan sebagian besar masa kecil mereka di sekolah, fase yang bertepatan dengan pertumbuhan fisik dan mental mereka. School is the child's workplace. Lingkungan pendidikan yang sehat sangat penting untuk kesehatan dan kesejahteraan siswa (Toosi et al., 2015). School is the child's workplace. Anak-anak menghabiskan banyak waktu mereka di sekolah, dalam keadaan yang seringkali tidak optimal (Howard Frumkin, Robert Geller, I. Leslie Rubin, 2009). Siswa menghabiskan setidaknya $20 \%$ dari waktu mereka di sekolah. Pelatihan, pendidikan, dan kepribadian para siswa ini tergantung pada metode pendidikan yang tepat, ruang fisik yang tepat, dan juga lingkungan mental yang menguntungkan (Sharifirad, 2011). Pengenalan upaya pemeliharaan kesehatan diri dapat diajarkan pada anak secara langsung maupun tidak langsung. Sehingga diharapkan anak memiliki kesiapan dan kesanggupan untuk menjaga kesehatan dan keselamatan diri sendiri.

Dalam siklus kehidupan, anak usia dini merupakan suatu periode yang sangat sensitif dengan pertumbuhan dan perkembangan yang sangat cepat. Apabila mendapat layanan kesehatan termasuk asupan zat gizi yang tepat dan berkualitas, lingkungan yang sehat, dan stimulasi yang tepat akan berdampak pada pertumbuhan dan perkembangan yang optimal dan memiliki potensi yang tinggi untuk perkembangan kehidupan berikutnya. Periode ini disebut sebagai masa keemasan (the golden age periode). Sebaliknya, masa ini disebut juga masa kritis apabila mengalami gangguan akan berdampak serius dan panjang. Pendidikan yang dilakukan pada anak-anak sejak usia dini mengenai keselamatan merupakan cara membentuk pola pikir dan karakter pada anak-anak (Santi \& Sugiyanto, 2016).

Berdasarkan hasil observasi awal di TK Tunas Mekar I Dalung, dapat diketahui bahwa upaya pengenalan perilaku kesehatan belum dilaksanakan secara optimal. Proses pembelajaran yang secara khusus dilakukan untuk memperkenalkan perilaku kesehatan masih jarang dilakukan. Persepsi dan pengetahuan orang tua mengenai kesehatan yang masih minim juga dapat mempengaruhi perilaku kesehatan anak (Putri Abadi \& Suparno, 2019). Hal ini mengakibatkan tidak semua anak dapat menunjukan perilaku kesehatan dan keselamatan, seperti belum mengetahui dan mau mengkonsumsi makanan yang bergizi, kurang mengetahui sumber atau bahan berbahaya disekitar, belum menunjukan sikap menjaga kebersihan diri sendiri dan lingkungan sekitar. Apabila perilaku tersebut dibiarkan, maka akan berdampak buruk bagi kesehatan anak, dan pada akhirnya akan mengganggu pula pada pertumbuhan dan perkembangan anak.

Penelitaian terdahulu yang dilakukan oleh (Astuti, 2016) mengenai Perilaku sehat anak usia dini di lingkungan lembaga PAUD Purwomukti belum dilaksanakan dengan baik oleh peserta didik. Hal ini ditunjukan oleh perilaku-perilaku yang berada dalam kriteria cukup diantaranya perilaku kebersihan lingkungan $58 \%$, perilaku terhadap kebersihan diri $63 \%$ dan perilaku keseimbangan (kebutuhan tidur dan aktifitas) 65\%. Sedang perilaku makan dan minum $75 \%$; perilaku terhadap sakit dan penyakit $82 \%$ berada dalam kriteria baik. Sehingga lembaga PAUD harus terus dilakukan pembinaan serta pendampingan supaya perilaku sehat dapat menjadi gaya hidup anak usia dini.

Tidak semua anak mampu menunjukkan perilaku sosial seperti yang diharapkan. Upaya untuk membantu pengembangan sosial anak, selayaknya ada kerjasama antara orang tua dan guru (Rohayati, 2013). Perilaku sosial berhubungan erat pada perilaku anak dalam menyesuaikn diri dengan aturan-aturan masyarakat di lingkungan sekitar. Perilaku sosial diperoleh anak melalui kematangan dan kesempatan belajar dari berbagai stimulus yang diberikan lingkungannya (A., 2016). Permasalahan perilaku emosional anak usia PAUD yang dikomunikasikan dalam kaitannya dengan pengendalian perilaku emosional anak antara guru dengan orang tua tentunya banyak terkait dengan kenyataan sehari-hari, 
perilaku yang dikomunikasikan biasanya: (1) agresivitas; (2) kecemasan; (3) Menarik diri (Withdraw); (4) Takut berlebihan (Ashary, 2015).

Sama dengan perilaku sosial, perilaku kesehatan dan keselamatan yang juga membutuhkan penanganan khusus. Aplikasi strategi pembelajaran yang digunakan dilapangaan, secara khusus belum mampu menyentuh upaya pembiasaan kesehatan dan keselamatan anak usia dini. Dibutuhkan suatu strategi yang tepat dalam mengembangkan kemampuan perilaku keselamatan anak. Untuk mencapai hal tersebut diperlukan suatu proses pembelajaran yang bersifat student centered, proses pembelajaran yang memberikan kesempatan kepada siswa untuk melakukan sesuatu (pembelajaran langsung), kemudian memberikan kesempatan pada siswa untuk mengkonstruksikan sendiri pengetahuannya serta mengembangkan kreativitasnya. Model pembelajaran berperan sebagai panduan dalam merancang pembelajaran untuk membantu peserta didik mencapai tujuan pembelajaran, dengan model pembelajaran tersebut guru dapat membantu siswa untuk mendapatkan ide, keterampilan, cara berpikir, dan mengekspresikan ide diri sendiri (Trianto, 2007). Experiential Learning adalah suatu model pembelajaran yang mengaktifkan siswa dalam proses belajar mengajar untuk membangun pengetahuan dan ketrampilan melalui pengalamannya secara langsung. Metode ini evektif dalam meningkatkan kemampuan kognitif siswa. Hasil penelitian (Sholihah \& Mahmudi, 2015) menunjukkan bahwa penerapan model experiential learning lebih efektif dari pembelajaran konvensional pada pembelajaran matematika materi bangun ruang sisi datar ditinjau dari prestasi belajar dan apresiasi siswa terhadap matematika

Berdasarkan penelitian kami sebelumnya (Suryaningsih, 2017) ditemukan bahwa implementasi Metode Experiential Learning dapat meningkatkan kreativitas Mahasiswa PGPAUD. Kreativitas memiliki kaitan yang erat dengan perilaku, karena dalam berperilaku seseorang dapat mengekpresikan (menunjukan) kreativitasnya. Sehingga kami menduga melalui penerapan metode Experiential Learning, juga dapat meningkatkan perilaku kesehatan anak usia dini.

\section{METODOLOGI}

Penelitian ini dirancang sebagai Penelitian Tindakan Kelas (classroom action research). Penelitian ini bertujuan untuk melihat efektifitas metode Experiential Learning dalam menumbuhkan perilaku kesehatan dan keselamatan anak, Sehingga diharapkan hasil dari penelitian ini dapat menjadi bahan pertimbangan pendidik anak usia dini dalam menentukan metode pembelajaran yang akan diterapkan.

Penelitian ini dirancang dalam dua siklus. Setiap siklus terdiri dari empat tahapan yaitu perencanaan tindakan, pelaksanaan tindakan, observsi/evaluasi, dan refleksi. Tahap pertama Penelitian diawali dengan melakukan studi pendahuluan berupa observasi awal terhadap proses pembelajaran anak usia dini. Hal ini dilakukan untuk mengidentifikasi permasalahan yang dihadapi dalam pembelajaran anak sehari-hari. Selanjutnya menetapkan dan menyusun rancangan tindakan pembelajaran dengan metode experiental learning. Tahap kedua yakni Pelaksanaan pembelajaran, dilaksanakan sesuai dengan rencana yang telah dirancang sebelumnya. Tahap ketiga meliputi proses pengamatan (observasi) dan evaluasi terhadap perilaku kesehatan dan keselamatan anak usia dini. Tahap keempaat yakni refleksi yang dimaksud adalah mengingat dan merenungkan kembali suatu tindakan yang telah dicatat dalam proses observasi. Refleksi dilakukan untuk memahami proses, masalah persoalan, dan kendala yang nyata dalam tindakan strategis. Strategi memiliki aspek evaluatif, untuk menilai apakah pengaruh memang diinginkan, dan memberikan saransaran tentang cara-cara untuk meneruskan pelaksanaan.

Subjek penelitian tindakan kelas ini adalah anak usia dini di TK Tunas Mekar II Dalung, yang berjumlah 21 orang anak. Objek penelitian tindakan kelas yang dilakukan terhadap subjek penelitian adalah (1) Penerapan metode Experiential learning dalam proses pembelajaran anak usia dini, dan (2) Peningkatan perilaku kesehatan dan keselamatan anak 190 | Jurnal Obsesi : Jurnal Pendidikan Anak Usia Dini, 4(1), 2020 
usia dini, sesuai dengan yang diatur dalam Permendikbud nomor 137 tahun 2014 (Kemendikbud, 2014).

Metode pengumpulan data yang digunakan dalam penelitian ini yakni melalui observasi. Proses pengumpulan data melalui teknik observasi ini menggunakan panduan rubrik untuk merekam data mengenai perilaku kesehatan dan keselamatan yang ditunjukan anak dalam proses pembelajaran dengan menerapkan metode Experiential learning. Penyusunan format observasi dilakukan berdasarkan definisi operasional variabel dan indikator yang digunakan. Kisi-kisi instrumen pengamatan perilaku kesehatan dan keselamatan anak usia 5-6 seperti yang tercantum dalam Permendikbud 137 Tahun 2014 (Kemendikbud, 2014), dapat diamati pada tabel 1 berikut ini.

Tabel 1 Kisi-kisi Instrumen Perilaku Kesehatan dan Keselamatan Anak Usia Dini

\begin{tabular}{|c|c|c|}
\hline $\begin{array}{c}\text { Lingkup } \\
\text { Perkembang } \\
\text { an }\end{array}$ & Tingkat Pencapaian Perkembangan & Indikator \\
\hline $\begin{array}{l}\text { C. Kesehatan } \\
\text { dan Perilaku } \\
\text { Keselamatan }\end{array}$ & $\begin{array}{l}\text { 1. Berat badan sesuai tingkat usia } \\
\text { 2. Tinggi badan sesuai standar usia } \\
\text { 3. Berat badan sesuai dengan } \\
\text { standar tinggi badan } \\
\text { 4. Lingkar kepala sesuai tingkat } \\
\text { usia } \\
\text { 5. Menutup hidung dan mulut } \\
\text { (misal, ketika batuk dan bersin) } \\
\text { 6. Membersihkan, dan } \\
\text { membereskan tempat bermain } \\
\text { 7. Mengetahui situasi yang } \\
\text { membahayakan diri } \\
\text { 8. Memahami tata cara } \\
\text { menyeberang } \\
\text { 9. Mengenal kebiasaan buruk bagi } \\
\text { kesehatan }\end{array}$ & $\begin{array}{l}\text { d. Menutup hidung dan mulut (misal, } \\
\text { ketika batuk dan bersin) } \\
\text { e. Membersihkan, dan membereskan } \\
\text { tempat bermain } \\
\text { f. Mengetahui situasi yang } \\
\text { membahayakan diri } \\
\text { g. Memahami tata cara menyebrang } \\
\text { h. Mengenal kebiasaan buruk bagi } \\
\text { kesehatan }\end{array}$ \\
\hline
\end{tabular}

(dikembangangkan berdasarkan Permendikbud no 137 tahun 2014)

Data peningkatan perilaku kesehatan dan keselamatan anak dianalisis secara deskriptif. Aktivitas-aktivitas yang muncul selama proses pembelajaran sehubungan dengan implementasi tindakan dapat dihtung dengan pedoman observasi yang dilaksanakan. Keberhasilan anak dalam peningkatan perilaku kesehatan dan keselamatan dikatagorikan menjadi lima katagori yaitu sangat rendah, rendah, sedang, tinggi dan sangat tinggi.

Cara menghitungnya adalah dengan mencari rata-rata, minimal memenuhi katagori sedang. Tingkat kemampuan kognitif anak ditentukan dengan membandingkan persentase penguasaan kreativitas ke dalam konversi Penilaian Acuan Patokan (PAP) skala lima (Agung, 2014), dengan kriteria sangat rendah, rendah, sedang, tinggi, dan sangat tinggi.

Kriteria keberhasilan dalam penelitian ini adalah jika terjadi peningkatan perilaku kesehatan dan keselamatan anak melalui penerapan metode experiential learning. Indikator keberhasilan dalam penelitian ini apabila minimal $80 \%$ dari jumlah anak memenuhi kategori sedang.

\section{HASIL DAN PEMBAHASAN}

Hasil yang diperoleh dalam penelitian ini meliputi peningkatan kemampuan kognitif anak usia dini yang belajar melalui Pendekatan tematik sains berbasis permainan. Pada tahap awal penelitian ini diadakan observasi mengenai kemampuan kognitif anak. Berrdasarkan Pedoman Konversi Penilaian Acuan Patokan (PAP) Nasional, dapat ditentukan katagori kemampuan kognitif anak pada observasi awal, seperti yang tersaji pada tabel 2 berikut ini. 
DOI: $10.31004 /$ obsesi.v4i1.317

Tabel 2 Data Perilaku Kesehatan dan Keselamatan Anak Usia Dini Observasi Awal

\begin{tabular}{|c|c|c|c|c|c|c|c|c|c|c|c|c|c|c|}
\hline \multirow[t]{2}{*}{ No } & \multirow{2}{*}{$\begin{array}{l}\text { Sub } \\
\text { yek }\end{array}$} & \multicolumn{8}{|c|}{$\begin{array}{c}\text { Indikator Perrilaku Kesehatan dan } \\
\text { Keselamatan AUD }\end{array}$} & \multirow{2}{*}{$\begin{array}{c}\text { Jumla } \\
\text { h } \\
\text { Total }\end{array}$} & \multirow{2}{*}{$\begin{array}{l}\text { Rata- } \\
\text { rata }\end{array}$} & \multirow{2}{*}{$\begin{array}{c}\text { Persentase } \\
\text { penguasa-an }\end{array}$} & \multirow[t]{2}{*}{ Katagori } & \multirow{2}{*}{$\begin{array}{l}\text { Ketun- } \\
\text { tasan }\end{array}$} \\
\hline & & A & B & $\mathrm{C}$ & $\mathrm{D}$ & E & $\mathrm{F}$ & G & $\mathrm{H}$ & & & & & \\
\hline 1 & $\mathrm{~A}$ & 3 & 3 & 5 & 4 & 3 & 2 & 3 & 3 & 26 & 3,25 & 65,00 & Sedang & Tuntas \\
\hline 2 & B & 3 & 2 & 3 & 3 & 3 & 2 & 2 & 3 & 21 & 2,63 & 52,50 & $\begin{array}{l}\text { Sangat } \\
\text { Rendah }\end{array}$ & $\begin{array}{l}\text { Belum } \\
\text { Tuntas }\end{array}$ \\
\hline 3 & C & 4 & 3 & 4 & 3 & 4 & 2 & 3 & 3 & 26 & 3,25 & 65,00 & Sedang & Tuntas \\
\hline 4 & $\mathrm{D}$ & 4 & 2 & 4 & 4 & 4 & 2 & 2 & 3 & 25 & 3,13 & 62,50 & Rendah & $\begin{array}{l}\text { Belum } \\
\text { Tuntas }\end{array}$ \\
\hline 5 & $\mathrm{E}$ & 4 & 2 & 3 & 3 & 5 & 2 & 2 & 4 & 25 & 3,13 & 62,50 & Rendah & $\begin{array}{l}\text { Belum } \\
\text { Tuntas }\end{array}$ \\
\hline 6 & $\mathrm{~F}$ & 3 & 2 & 4 & 4 & 4 & 2 & 3 & 4 & 26 & 3,25 & 65,00 & Sedang & Tuntas \\
\hline 7 & G & 3 & 2 & 3 & 3 & 3 & 2 & 2 & 3 & 21 & 2,63 & 52,50 & $\begin{array}{l}\text { Sangat } \\
\text { Rendah }\end{array}$ & $\begin{array}{l}\text { Belum } \\
\text { Tuntas }\end{array}$ \\
\hline 8 & $\mathrm{H}$ & 4 & 2 & 3 & 3 & 4 & 2 & 3 & 3 & 24 & 3,00 & 60,00 & Rendah & $\begin{array}{l}\text { Belum } \\
\text { Tuntas }\end{array}$ \\
\hline 9 & I & 3 & 2 & 2 & 2 & 3 & 3 & 2 & 2 & 19 & 2,38 & 47,50 & $\begin{array}{l}\text { Sangat } \\
\text { Rendah }\end{array}$ & $\begin{array}{l}\text { Belum } \\
\text { Tuntas }\end{array}$ \\
\hline 10 & $\mathrm{~J}$ & 4 & 2 & 4 & 5 & 4 & 3 & 3 & 3 & 28 & 3,50 & 70,00 & Sedang & Tuntas \\
\hline 11 & $\mathrm{~K}$ & 4 & 2 & 4 & 5 & 5 & 3 & 3 & 3 & 29 & 3,63 & 72,50 & Sedang & Tuntas \\
\hline 12 & $\mathrm{~L}$ & 4 & 2 & 4 & 3 & 4 & 3 & 3 & 2 & 25 & 3,13 & 62,50 & Rendah & $\begin{array}{l}\text { Belum } \\
\text { Tuntas }\end{array}$ \\
\hline 13 & M & 4 & 2 & 3 & 3 & 2 & 3 & 3 & 2 & 22 & 2,75 & 55,00 & Rendah & $\begin{array}{l}\text { Belum } \\
\text { Tuntas }\end{array}$ \\
\hline 14 & $\mathrm{~N}$ & 1 & 2 & 3 & 3 & 2 & 2 & 2 & 2 & 17 & 2,13 & 42,50 & $\begin{array}{l}\text { Sangat } \\
\text { Rendah }\end{array}$ & $\begin{array}{l}\text { Belum } \\
\text { Tuntas }\end{array}$ \\
\hline 15 & $\mathrm{O}$ & 4 & 2 & 3 & 4 & 3 & 2 & 2 & 2 & 22 & 2,75 & 55,00 & Rendah & $\begin{array}{l}\text { Belum } \\
\text { Tuntas }\end{array}$ \\
\hline 16 & $\mathrm{P}$ & 4 & 2 & 3 & 3 & 4 & 2 & 2 & 2 & 22 & 2,75 & 55,00 & Rendah & $\begin{array}{l}\text { Belum } \\
\text { Tuntas }\end{array}$ \\
\hline 17 & Q & 4 & 2 & 4 & 4 & 4 & 2 & 2 & 2 & 24 & 3,00 & 60,00 & Rendah & $\begin{array}{l}\text { Belum } \\
\text { Tuntas }\end{array}$ \\
\hline 18 & $\mathrm{R}$ & 3 & 2 & 3 & 3 & 3 & 2 & 2 & 3 & 21 & 2,63 & 52,50 & $\begin{array}{l}\text { Sangat } \\
\text { Rendah }\end{array}$ & $\begin{array}{l}\text { Belum } \\
\text { Tuntas }\end{array}$ \\
\hline 19 & $S$ & 3 & 3 & 4 & 4 & 4 & 2 & 2 & 3 & 25 & 3,13 & 62,50 & Rendah & $\begin{array}{l}\text { Belum } \\
\text { Tuntas }\end{array}$ \\
\hline 20 & $\mathrm{~T}$ & 3 & 2 & 4 & 4 & 5 & 2 & 3 & 2 & 25 & 3,13 & 62,50 & Rendah & $\begin{array}{l}\text { Belum } \\
\text { Tuntas }\end{array}$ \\
\hline 21 & $\mathrm{U}$ & 4 & 2 & 4 & 5 & 5 & 3 & 3 & 2 & 28 & 3,50 & 70,00 & Sedang & Tuntas \\
\hline Min & & & & & & & & & & & & 42,50 & & \\
\hline Max & & & & & & & & & & & & 72,50 & & \\
\hline Mean & & & & & & & & & & & & 59,64 & & \\
\hline Media & & & & & & & & & & & & 62,50 & & \\
\hline Modu & & & & & & & & & & & & 62,5 & & \\
\hline Stand & ar Dev & & & & & & & & & & & 7,63 & & \\
\hline
\end{tabular}

Keterangan Indikator :

A : Mengenal makanan bergizi

B : Mengkonsumsi makanan bergizi

C : Mengikuti kegiatan olahraga

D : Menutup hidung dan mulut (misal, ketika batuk dan bersin)

E : Membersihkan, dan membereskan tempat bermain

F : Mengetahui situasi yang membahayakan diri

G : Memahami tata cara menyebrang

$\mathrm{H}$ : Mengenal kebiasaan buruk bagi kesehatan 
Berdasarkan tabel tersebut dapat diketahui bahwa penerapan perilaku kesehatan dan keselamatan anak usia dini masih rendah. Persentase ketuntasan hanya dicapai oleh 6 anak $(28,58 \%)$, dengan katagori sedang. Sebanyak 15 anak (71,41\%) masih berada pada katagori rendah (10 orang) dan sangat rendah (5 orang). Untuk itu perlu diberikan suatu tindak lanjut sebagai upaya menumbuhkan perilaku kesehatan dan keselamatan pada anak usia dini.

Upaya yang diberikan untuk menumbuhkan perilaku kesehatan dan keselamatan pada anak usia dini yakni melalui penerapan metode Experiential learning dalam proses pembelajaran. Metode ini menekankan pada sebuah pembelajaran yang holistik dalam proses belajar. Dalam metode ini pengalaman memmpunyai peran sentral dalam proses belajar. Sebagaimana yang didefinisikan Association for Experiential Education (AEE) mendefinisikan "experiential education is a process through which a learner construct knowledge, skill, and value from direct experiences (Xiong Huang, 2011). "Pendidikan berbasis pengalaman merupakan sebuah proses dimana para pelajar membangun pengetahuan, keterampilan dan nilai dari pengalaman langsung.

Berikut pada gambar 1 ditunjukan proses pembelajaran dengan penerapan metode experiential learning pada siklus I.

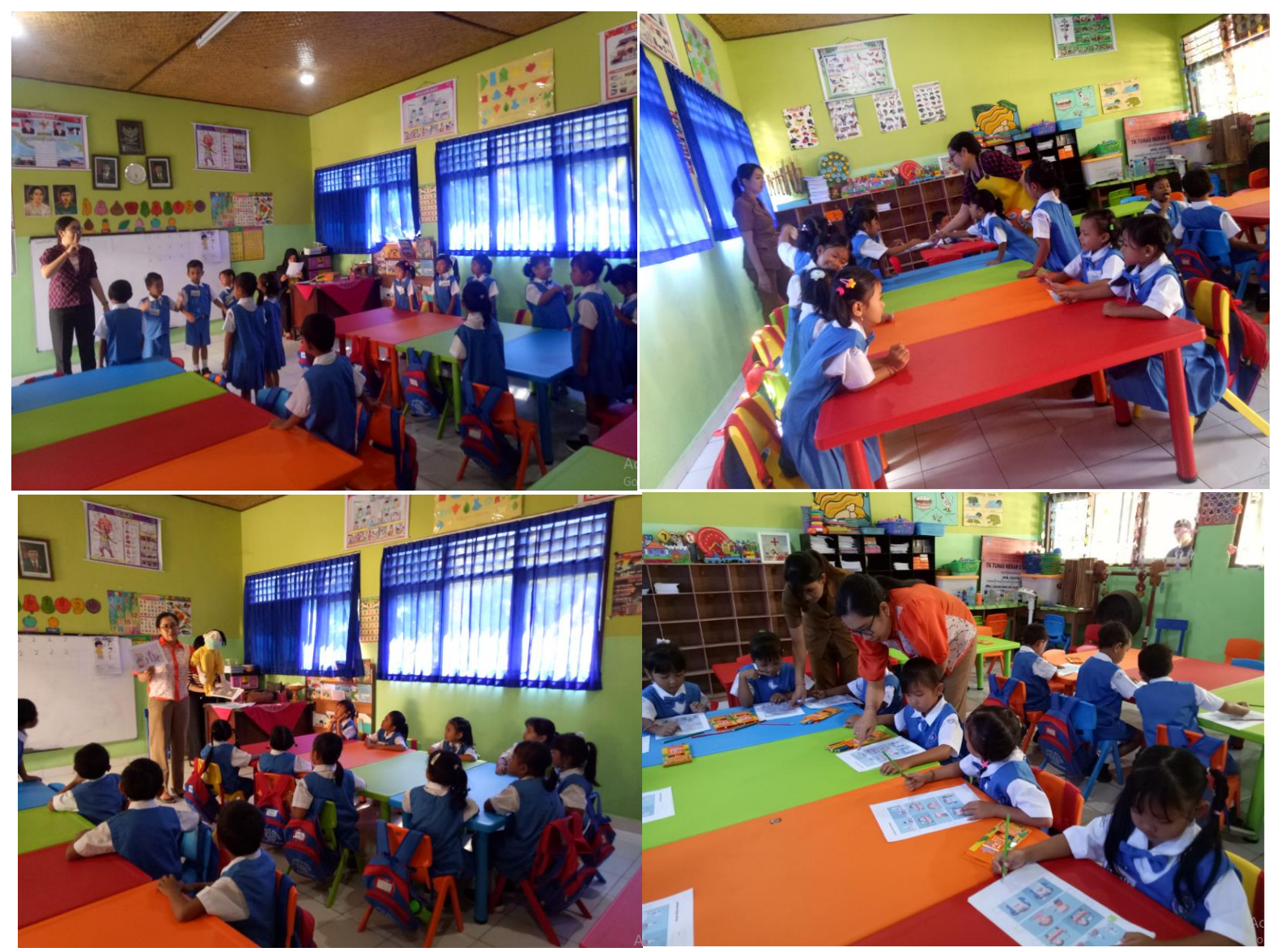

Gambar 1. Proses Pembelajaran Pada Siklus I.

Proses pemantauan kemampuan kognitif anak dilakukan selama proses pembelajaran berlangsung. Secara rinci ketuntasan kemampuan kognitif anak dengan menggunakan pendekatan tematik sains berbasis permainan pada siklus I, dapat diperhatikan pada tabel 3 berikut ini. 
Tabel 3 Data Perilaku Kesehatan dan Keselamatan Anak Usia Dini pada Siklus I

\begin{tabular}{|c|c|c|c|c|c|c|c|c|c|c|c|c|c|c|}
\hline \multirow{3}{*}{ No } & \multirow{3}{*}{$\begin{array}{l}\text { Sub } \\
\text { yek }\end{array}$} & \multirow{2}{*}{\multicolumn{8}{|c|}{$\begin{array}{c}\text { Indikator Perrilaku Kesehatan dan } \\
\text { Keselamatan AUD }\end{array}$}} & \multirow{3}{*}{$\begin{array}{c}\text { Jumla } \\
\text { h } \\
\text { Total }\end{array}$} & \multirow{3}{*}{$\begin{array}{l}\text { Rata- } \\
\text { rata }\end{array}$} & \multirow{3}{*}{$\begin{array}{l}\text { Persentas } \\
\text { e } \\
\text { penguasa } \\
\text { an } \\
\end{array}$} & \multirow{3}{*}{ Katagori } & \multirow{3}{*}{ Ketuntasan } \\
\hline & & & & & & & & & & & & & & \\
\hline & & A & B & C & $\mathrm{D}$ & $\mathrm{E}$ & $\mathrm{F}$ & G & $\mathrm{H}$ & & & & & \\
\hline 1 & A & 4 & 5 & 5 & 4 & 4 & 3 & 4 & 5 & 34 & 4,25 & 85,00 & Tinggi & Tuntas \\
\hline 2 & B & 3 & 3 & 3 & 4 & 3 & 3 & 3 & 3 & 25 & 3,13 & 62,50 & Rendah & $\begin{array}{l}\text { Belum } \\
\text { Tuntas }\end{array}$ \\
\hline 3 & $\mathrm{C}$ & 3 & 4 & 4 & 3 & 4 & 3 & 3 & 5 & 29 & 3,63 & 72,50 & Sedang & Tuntas \\
\hline 4 & $\mathrm{D}$ & 3 & 3 & 4 & 4 & 5 & 3 & 3 & 5 & 30 & 3,75 & 75,00 & Sedang & Tuntas \\
\hline 5 & $\mathrm{E}$ & 4 & 4 & 3 & 4 & 5 & 3 & 3 & 4 & 30 & 3,75 & 75,00 & Sedang & Tuntas \\
\hline 6 & $\mathrm{~F}$ & 3 & 3 & 4 & 4 & 4 & 3 & 5 & 4 & 30 & 3,75 & 75,00 & Sedang & Tuntas \\
\hline 7 & G & 3 & 3 & 3 & 3 & 3 & 3 & 4 & 3 & 25 & 3,13 & 62,50 & Rendah & $\begin{array}{l}\text { Belum } \\
\text { Tuntas }\end{array}$ \\
\hline 8 & $\mathrm{H}$ & 2 & 3 & 3 & 3 & 4 & 3 & 5 & 5 & 28 & 3,50 & 70,00 & Sedang & Tuntas \\
\hline 9 & I & 2 & 1 & 3 & 2 & 3 & 4 & 4 & 4 & 23 & 2,88 & 57,50 & Rendah & $\begin{array}{l}\text { Belum } \\
\text { Tuntas }\end{array}$ \\
\hline 10 & $\mathrm{~J}$ & 4 & 4 & 4 & 5 & 4 & 4 & 4 & 5 & 34 & 4,25 & 85,00 & Tinggi & Tuntas \\
\hline 11 & K & 4 & 4 & 4 & 5 & 5 & 5 & 4 & 5 & 36 & 4,50 & 90,00 & $\begin{array}{l}\text { Sangat } \\
\text { Tinggi }\end{array}$ & Tuntas \\
\hline 12 & $\mathrm{~L}$ & 2 & 3 & 4 & 3 & 4 & 4 & 4 & 4 & 28 & 3,50 & 70,00 & Sedang & Tuntas \\
\hline 13 & M & 2 & 3 & 3 & 3 & 2 & 4 & 4 & 2 & 23 & 2,88 & 57,50 & Rendah & $\begin{array}{l}\text { Belum } \\
\text { Tuntas }\end{array}$ \\
\hline 14 & $\mathrm{~N}$ & 2 & 3 & 3 & 3 & 2 & 3 & 3 & 2 & 21 & 2,63 & 52,50 & $\begin{array}{l}\text { Sangat } \\
\text { Rendah }\end{array}$ & $\begin{array}{l}\text { Belum } \\
\text { Tuntas }\end{array}$ \\
\hline 15 & $\mathrm{O}$ & 1 & 2 & 3 & 4 & 3 & 3 & 3 & 4 & 23 & 2,88 & 57,50 & Rendah & $\begin{array}{l}\text { Belum } \\
\text { Tuntas }\end{array}$ \\
\hline 16 & $\mathrm{P}$ & 3 & 3 & 3 & 3 & 4 & 3 & 3 & 4 & 26 & 3,25 & 65,00 & Sedang & Tuntas \\
\hline 17 & Q & 3 & 3 & 4 & 4 & 4 & 3 & 3 & 4 & 28 & 3,50 & 70,00 & Sedang & Tuntas \\
\hline 18 & $\mathrm{R}$ & 3 & 3 & 3 & 3 & 3 & 3 & 3 & 3 & 24 & 3,00 & 60,00 & Rendah & $\begin{array}{l}\text { Belum } \\
\text { Tuntas }\end{array}$ \\
\hline 19 & S & 2 & 3 & 4 & 4 & 4 & 3 & 4 & 3 & 27 & 3,38 & 67,50 & Sedang & Tuntas \\
\hline 20 & $\mathrm{~T}$ & 2 & 3 & 4 & 4 & 5 & 3 & 5 & 4 & 30 & 3,75 & 75,00 & Sedang & Tuntas \\
\hline 21 & $\mathrm{U}$ & 4 & 4 & 4 & 5 & 5 & 4 & 4 & 4 & 34 & 4,25 & 85,00 & Tinggi & Tuntas \\
\hline Min & & & & & & & & & & & & 52,50 & & \\
\hline Max & & & & & & & & & & & & 90,00 & & \\
\hline Mean & & & & & & & & & & & & 70,00 & & \\
\hline Medi & & & & & & & & & & & & 70,00 & & \\
\hline Modu & & & & & & & & & & & & 75 & & \\
\hline Stand & ar De & & & & & & & & & & & 10,49 & & \\
\hline
\end{tabular}

Pada tabel 3, tingkat ketuntasan perilaku kesehatan dan keselamatan anak usia dini mulai mengalami peningkatan. Ketuntasan dicapai oleh 14 anak (66,67\%), dengan katagori sedang (10 anak), tinggi ( 3 anak) dan sangat tinggi (1 anak). Pada akhir siklus I ini hanya menyisakan 7 anak $(33,33 \%)$ yang belum mencapai batas ketuntasan dengan katagori rendah.

Penerapan metode Experiental Learning mampu meningkatkan Perilaku kesehatan dan keselamatan anak. Berdasarkan hasil pada siklus I, secara umum terjadi peningkatan pada setiap indikator perilaku kesehatan dan keselamatan anak, namun masih ada anak yang memperoleh katagori rendah. Sehingga untuk meningkatkan perilaku kesehatan dan keselamatan anak, penerapan metode experiental learning kembali dilanjutkan pada siklus II. Pada siklus ke II dilakukan perbaikan terhadap kelemahan yang terjadi di siklus I, yakni dengan memvariasikan media, dan sumber belajar. Pada gambar 2 berikut ini dapat diamati proses pembelajaran dengan menggunakan metode experiental learning pada siklus II. 

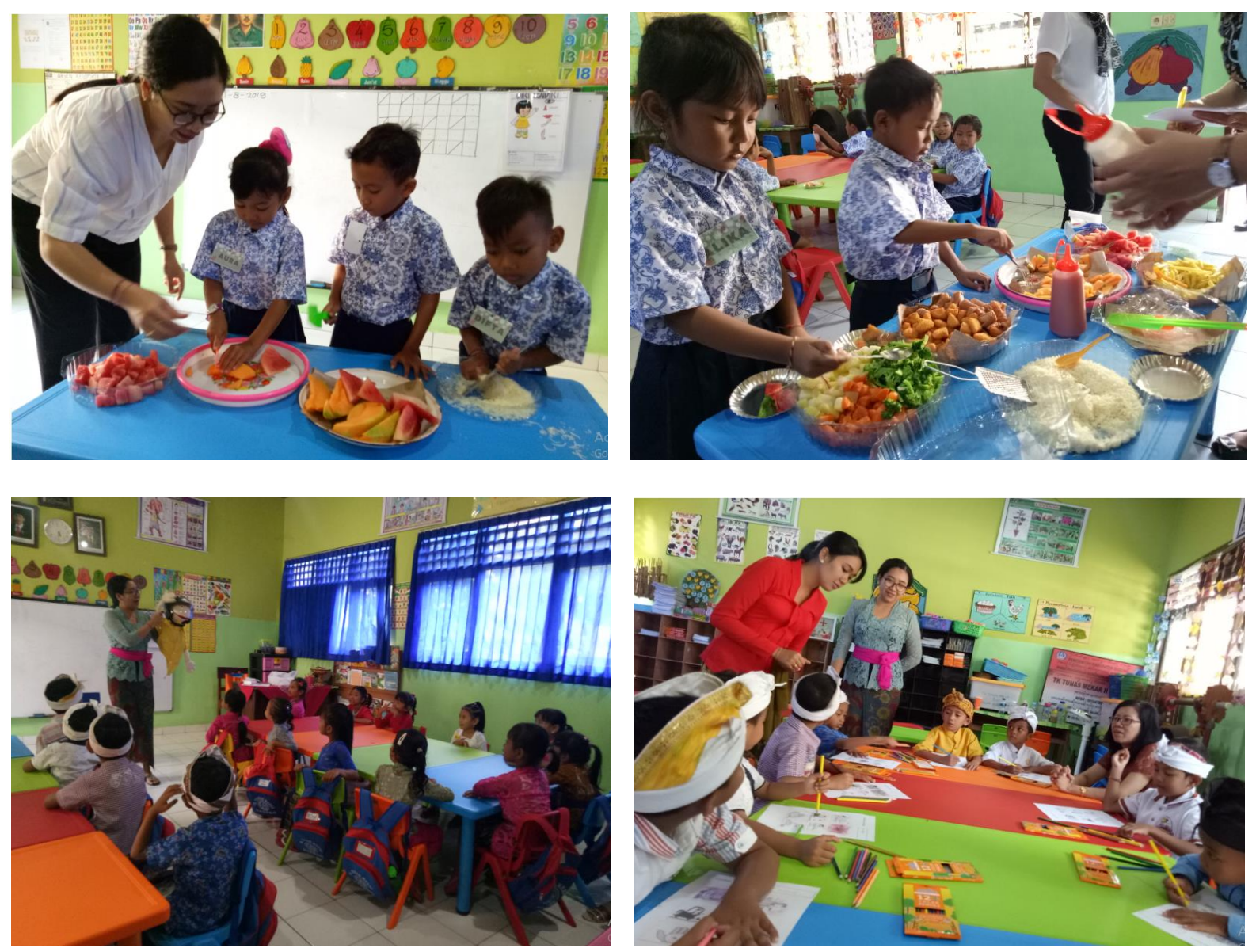

Gambar 3. Proses Pembelajaran Pada Siklus II.

Pada pelaksanaan proses pembelajaran siklus ke II, kembali terjadi peningkatan perilaku kesehatan dan keselamatan pada anak. Secara rinci ketuntasan perilaku kesehatan dan keselamatan anak dengan menerapkan metode experiental learning pada siklus II, ditunjukan pada tabel 4 berikut ini.

Tabel 4 Data Tingkat Kemampuan Kognitif Anak pada Siklus II

\begin{tabular}{ccccccccccccccc}
\hline $\begin{array}{c}\text { N } \\
\text { o }\end{array}$ & $\begin{array}{c}\text { Subye } \\
\text { k }\end{array}$ & A & B & C & D & E & F & G & H & Total & $\begin{array}{c}\text { Kata- } \\
\text { rata }\end{array}$ & $\begin{array}{c}\text { Persentas } \\
\text { penguasa } \\
\text { an }\end{array}$ & Katagori & $\begin{array}{c}\text { Ketun- } \\
\text { tasan }\end{array}$ \\
\hline 1 & A & 5 & 4 & 4 & 5 & 5 & 5 & 5 & 5 & 38 & 4,75 & 95,00 & Sangat Tinggi & Tuntas \\
2 & B & 4 & 5 & 4 & 4 & 4 & 5 & 3 & 4 & 33 & 4,13 & 82,50 & Tinggi & Tuntas \\
3 & C & 5 & 4 & 4 & 3 & 3 & 4 & 4 & 4 & 31 & 3,88 & 77,50 & Sedang & Tuntas \\
4 & D & 4 & 4 & 4 & 4 & 3 & 4 & 4 & 4 & 31 & 3,88 & 77,50 & Sedang & Tuntas \\
5 & E & 4 & 4 & 4 & 4 & 4 & 4 & 4 & 5 & 33 & 4,13 & 82,50 & Tinggi & Tuntas \\
6 & F & 5 & 4 & 4 & 4 & 3 & 4 & 3 & 4 & 31 & 3,88 & 77,50 & Sedang & Tuntas \\
7 & G & 4 & 5 & 3 & 3 & 4 & 3 & 4 & 3 & 29 & 3,63 & 72,50 & Sedang & Tuntas \\
8 & H & 5 & 5 & 4 & 3 & 3 & 4 & 3 & 4 & 31 & 3,88 & 77,50 & Sedang & Tuntas \\
9 & I & 5 & 1 & 4 & 2 & 2 & 4 & 4 & 3 & 25 & 3,13 & 62,50 & Rendah & Belum \\
10 & J & 4 & 4 & 4 & 5 & 4 & 4 & 4 & 5 & 34 & 4,25 & 85,00 & Tinggi & Tuntas \\
11 & K & 5 & 5 & 5 & 5 & 5 & 4 & 4 & 4 & 37 & 4,63 & 92,50 & Sangat Tinggi & Tuntas \\
12 & L & 5 & 3 & 4 & 3 & 3 & 4 & 4 & 4 & 30 & 3,75 & 75,00 & Sedang & Tuntas \\
13 & M & 5 & 3 & 4 & 3 & 3 & 4 & 2 & 3 & 27 & 3,38 & 67,50 & Sedang & Tuntas \\
14 & $\mathrm{~N}$ & 4 & 3 & 4 & 3 & 2 & 3 & 3 & 3 & 25 & 3,13 & 62,50 & Rendah & Belum \\
\hline
\end{tabular}


DOI: $10.31004 /$ obsesi.v4i1.317

\begin{tabular}{|c|c|c|c|c|c|c|c|c|c|c|c|c|c|c|}
\hline \multirow{2}{*}{$\begin{array}{l}\mathrm{N} \\
\mathrm{o}\end{array}$} & \multirow{2}{*}{$\begin{array}{l}\text { Subye } \\
\mathrm{k}\end{array}$} & \multicolumn{8}{|c|}{$\begin{array}{c}\text { Indikator Perrilaku Kesehatan dan } \\
\text { Keselamatan AUD }\end{array}$} & \multirow{2}{*}{$\begin{array}{c}\text { Jumla } \\
\text { h } \\
\text { Total }\end{array}$} & \multirow{2}{*}{$\begin{array}{l}\text { Rata- } \\
\text { rata }\end{array}$} & \multirow{2}{*}{$\begin{array}{l}\text { Persentas } \\
\text { e } \\
\text { penguasa } \\
\text { an }\end{array}$} & \multirow{2}{*}{ Katagori } & \multirow{2}{*}{$\begin{array}{l}\text { Ketun- } \\
\text { tasan }\end{array}$} \\
\hline & & A & B & C & $\mathrm{D}$ & E & $\mathrm{F}$ & G & $\mathrm{H}$ & & & & & \\
\hline & & & & & & & & & & & & & & Tuntas \\
\hline 15 & $\mathrm{O}$ & 4 & 3 & 4 & 4 & 3 & 4 & 3 & 4 & 29 & 3,63 & 72,50 & Sedang & Tuntas \\
\hline 16 & $\mathrm{P}$ & 4 & 2 & 4 & 3 & 3 & 4 & 4 & 4 & 28 & 3,50 & 70,00 & Sedang & Tuntas \\
\hline 17 & $\mathrm{Q}$ & 4 & 3 & 4 & 4 & 2 & 4 & 4 & 4 & 29 & 3,63 & 72,50 & Sedang & Tuntas \\
\hline 18 & $\mathrm{R}$ & 4 & 4 & 4 & 3 & 2 & 4 & 4 & 4 & 29 & 3,63 & 72,50 & Sedang & Tuntas \\
\hline 19 & $S$ & 4 & 5 & 4 & 4 & 3 & 4 & 4 & 4 & 32 & 4,00 & 80,00 & Tinggi & Tuntas \\
\hline 20 & $\mathrm{~T}$ & 4 & 4 & 4 & 4 & 4 & 4 & 4 & 4 & 32 & 4,00 & 80,00 & Tinggi & Tuntas \\
\hline 21 & $\mathrm{U}$ & 5 & 5 & 4 & 5 & 4 & 4 & 4 & 4 & 35 & 4,38 & 87,50 & Tinggi & Tuntas \\
\hline Min & & & & & & & & & & & & 62,50 & & \\
\hline Mas & & & & & & & & & & & & 95,00 & & \\
\hline Mea & & & & & & & & & & & & 77,26 & & \\
\hline $\mathrm{Mec}$ & lian & & & & & & & & & & & 77,50 & & \\
\hline Mo & dus & & & & & & & & & & & 77,5 & & \\
\hline Star & dar Devi & & & & & & & & & & & 8,55 & & \\
\hline
\end{tabular}

Pada tabel 4, ditunjukan mengenai tingkat ketuntasan perilaku kesehatan dan keselamatan setiap anak pada Siklus II, terlihat adanya peningkatan setelah mengikuti proses pembelajaran dengan metode Experiential learning. Hal ini ditunjukan dari semakin meningkatnya jumlah ketuntasan perilaku kesehatan dan keselamatan anak usia dini, yakni 19 anak (90,48\%). Dua orang anak (9,52\%) masih belum mencapai tingkat ketuntasan yang ditentukan.

Penerapan metode Experiential learning mampu meningkatkan kemampuan perilaku kesehatan dan keselamatan anak usia dini. Hal ini dapat dilihat dari perkembangan kemampuan, dari saat observasi awal hingga akhir siklus II. Pada gambar 5.3 berikut, dapat diamati grafik perbandingan perilaku kesehatan dan keselamatan anak usia dini dari observasi awal hingga siklus II

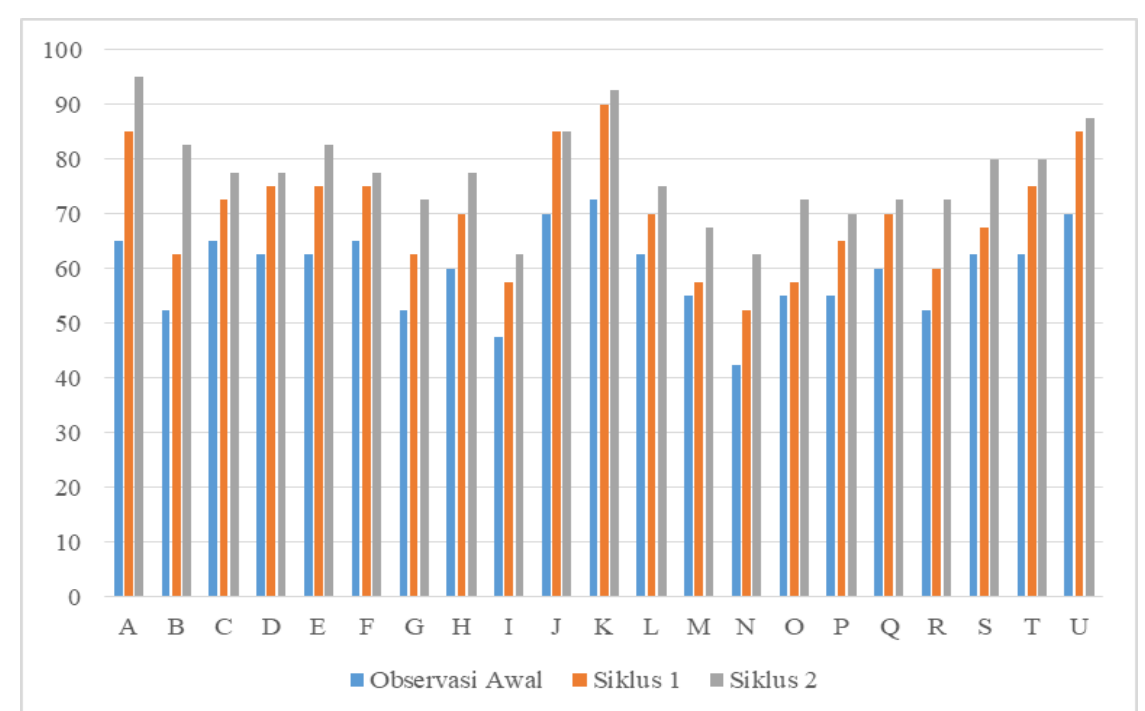

\section{Gambar 4 Diagram Perbandingan Perilaku Kesehatan dan Keselamatan Anak Usia Dini pada Observasi Awal, Siklus I Dan Siklus II}

Temuan tersebut didukung pula oleh beberapa kajian teoritis. Perilaku terjadi melalui proses adanya stimulus terhadap organisme, dan kemudian organisme tersebut merespon, maka teori Skinner dalam (Marmi, 2013) ini disebut teori 'S-O-R' (Stimulus-Organisme- 
Respons). Perubahan perilaku membutuhkan suatu proses, yaitu perubahan pengetahuan, perubahan sikap, dan perubahan tindakan (aplikasi tindakan) (Sari, 2012). Teori Planned Behavior menyatakan bahwa terdapat 3 determinan perilaku yang dapat mempengaruhi niat seseorang berperilaku yaitu sikap seseorang terhadap perilaku, norma subjektif yang berlaku serta persepsi atau kemampuan seseorang untuk mengontrol tingkah laku (Aprilia, 2015).

Experiential learning dapat didefinisikan sebagai tindakan untuk mencapai sesuatu berdasarkan pengalaman yang secara terus menerus mengalami perubahan guna meningkatkan keefektifan dari hasil belajar itu sendiri (Dumiyati, 2016). Proses belajar melalui metode ini, mengikutsertakan individu dalam suatu aktivitas, melihat kembali secara kritis aktivitas tersebut, memperoleh insight dari analisis yang dilakukannya dan mengambil hasilnya untuk mengubah perilaku (Sulistyowati, 2015). Selain itu Wahyuni menyebutkan bahwa Model experiential learning memberikan kesempatan pada peserta didik untuk mengalami keberhasilan dengan memberikan kebebasan peserta didik untuk memutuskan pengalaman apa yang menjadi fokus mereka, keterampilan-keterampilan apa yang ingin mereka kembangkan, dan bagaimana mereka membuat konsep dari pengalaman yang mereka alami tersebut (Wahyuni, 2010). Hal ini berbeda dengan pendekatan belajar tradisional dimana peserta didik menjadi pendengar pasif dan hanya guru yang mengendalikan proses belajar tanpa melibatkan peserta didik.

Menurut Ervin (Affrida, 2017), kemandirian anak usia prasekolah dibentuk melalui pola asuh membiasakan anak aktivitas sederhana untuk memenuhi kebutuhan diri seharihari untuk memenuhi kebutuhan diri sendiri. Mengalami berarti menghayati situasisituasi sebenarnya. Semua hasil belajar diperoleh melalui kegiatan sendiri. Dengan begitu peserta didik akan memperoleh pengalamannya untuk mengembangkan potensi yang ada dalam dirinya. Pengalaman merupakan seluruh kegiatan dan hasil yang komplek dari interaksi aktif manusia. Sebagai makhluk hidup yang sadar yang tumbuh dengan lingkungan di sekitarnya yang berubah dalam perjalanan waktu.

Hasil penelitian ini didukung pula oleh beberapa hasil penelitian berikut. Penelitian yang dilakukan oleh Arniansyah menyebutkan bahwa implementasi dari metode experiental learning dapat meningkatkan empati dan perilaku prososial anak-anak usia 6-12 tahun di Ruang Publik Terpadu Ramah Anak (RPTRA) Villa Anggrek Bintaro (Arniansyah, Nadhilla, Permatasari, Milani, \& Putri, 2018). Pada penelitian yang dilakukan oleh Widayanti (2018), ditemukan bahwa Pendidikan keselamatan diri di KB Gaharu Plus dapat meningkatkan pemahaman anak tentang bahaya dan cara menghindarinya. Pendidikan keselamatan diri ini merupakan salah satu upaya preventif untuk mengurangi kecelakaan di lembaga. Tahapan pembelajaran dalam penelitian tersebut meliputi belajar bahaya, survei bahaya, peta bahaya, dan cara menghindari bahaya. Anak-anak dapat mengikuti proses pendidikan keselamatan diri. Hasil dari penelitian ini yakni Sebagian besar (lebih dari 80\%) anak dapat mengikuti proses pendidikan keselamatan diri (Widayati, 2018).

Hasil penelitian ini juga didukung oleh temuan (Inten et al., 2019) yang menyebutkan bahwa penanaman kebiasaan sehat melalui Kegiatan eating clean merupakan kegiatan turunan dari sebuah program yang bernama clean to be clean makan pintar makan sehat di yayasan pendidikan Islam Al-Muqoddasah. Tujuan dari kegiatan ini yaitu membiasakan makan sehat sejak dini, melatih anak makan berbagai jenis makanan bergizi, memenuhi asupan gizi seimbang yang diperlukan tubuh anak, anak terbiasa memakan buah dan sayur, serta mempermudah orang tua dalam menyiapkan menu makan bekal untuk anak. Hasilnya dari 25 orang anak 90\% anak menyukai bekal makanan sehat yang bervariasi dan diolah dengan sehat dan 99\% respon orang tua pun merasakan dampak dari eating clean, yaitu ketika mereka merasa terbantu untuk menyiapkan menu harian anak dan pengenalkan makanan sehat untuk anak. 
Penelitian dari Eriska Riyanti menyebutkan bahwa Upaya pemeliharaan kesehatan gigi dan mulut seharusnya dilakukan sejak usia dini. Pada usia tersebut merupakan saat yang ideal untuk melatih kemampuan motorik seorang anak, termasuk diantaranya menyikat gigi. Proses pendidikan kesehatan gigi dan mulut merupakan suatu proses pendidikan yang timbul atas dasar kebutuhan akan kesehatan gigi dan mulut. Dalam penelitian ini, disimpulkan bahwa pendidikan kesehatan gigi dan mulut kepada anak sekolah harus diberikan secara berulang-ulang dan menarik, untuk itu dibutuhkan kerjasama yang baik antara siswa, guru,dan orangtua (Riyanti, 2009).

Upaya pengenalan dan pembiasaan perilaku kesehatan dan keselamatan perlu diupayakan sejak dini, dan dilakukan secara konsisten dengan melibatkan berbagai pihak. Pengenalan dapat dilakukan dengan menerapken metode experiental learning. Sehingga, Berdasarkan kajian teoritis, temuan-temuan penelitian sebelumnya serta hasil temuan penelitian ini, maka dapat dipahami bawa penerapan metode experiental learning dapat menumbuhkan perilaku kesehatan dan keselamatan pada anak usia dini.

\section{SIMPULAN}

Hasil penelitian menunjukan peningkatan perilaku kesehatan dan keselamatan anak usia dini. Sehingga dapat disimpulkan bahwa penerapan metode Experiential learning dapat menumbuhkan perilaku kesehatan dan keselamatan anak usia dini.

\section{UCAPAN TERIMAKASIH}

Pada kesempatan ini penulis menyampaikan ucapan terima kasih kepada pihakpihak yang telah banyak memberikan masukan dalam pelaksanaan penelitian ini, yakni ; (1) Dr. I Gusti Bagus Rai Utama, SE. M.MA., MA. selaku Rektor Universitas Dhyana Pura, yang telah memberikan motivasi dan rekomendasi guna kelancaran pelaksanaan penelitian. (2) Dr. Jaya Pramono, S.Pd., M.Par, selaku Dekan Fakultas Ekonomika dan Humaniora Universitas Dhyana Pura, yang telah banyak masukan dalam pelaksanaan penelitian ini. (3) Putu Chris Susanto, B.A., MBA., M.E selaku Ketua Lembaga Penelitian dan Pengabdian Masyarakat Universitas Dhyana Pura, yang telah banyak memberikan arahan dalam pelaksanaan penelitian ini. Dan (4) I Gusti Ayu Rai Citrawati, S.Pd., selaku Kepala Sekolah TK Tunas Mekar II Dalung yang telah memberikan ijin dalam pelaksanan penelitian ini. Karena dengan bantuan dari pihak-pihak tersebutlah maka penulis dapat melaksanakan penelitian, sesuai dengan yang direncanakan.

\section{DAFTAR PUSTAKA}

A., F. L. T. (2016). Perilaku Sosial Anak Usia Dini di Lingkungan Lokalisasi Guyangan 2016. JPUD - Jurnal Pendidikan Usia Dini, 10(1), 121-134. https:// doi.org/10.21009/JPUD.101.07

Affrida, E. N. (2017). Strategi Ibu dengan Peran Ganda dalam Membentuk Kemandirian Anak Usia Pra Sekolah. Jurnal Obsesi : Jurnal Pendidikan Anak Usia Dini, 1(2), 114. https:// doi.org/10.31004/obsesi.v1i2.24

Agung, A. (2014). Metode Penelitian Pendidikan. Malang: Aditya Media Publishing.

Aprilia, A. (2015). Perilaku Ibu dalam Memberikan Pendidikan Seks Usia Dini pada Anak Pra Sekolah (Studi Deskriptif Eksploratif di TK IT Bina Insani Kota Semarang). Jurnal Kesehatan Masyarakat, 3(1).

Arniansyah, A., Nadhilla, N., Permatasari, R. E., Milani, T., \& Putri, Y. W. A. (2018). Pelatihan Empati dan Perilaku Prososial pada Anak Usia 6-12 Tahun di Rptra Anggrek Bintaro. Jurnal Muara Ilmu Sosial, Humaniora, Dan Seni, 2(1), 432. https:// doi.org/10.24912/jmishumsen.v2i1.2064

Ashary, Y. (2015). Pengendalian Perilaku Emosional Anak TK Melalui Komunikasi Antara Guru Dengan Orang Tua di Kec. Biringkanaya Kota Makassar. Jurnal Komunikasi 
KAREBA, 4(4), 415-434.

Astuti, A. K. (2016). Pelaksanaan Perilaku Sehat pada Anak Usia Dini di PAUD Purwomukti Desa Batur Kecamatan Getasan. Scholaria : Jurnal Pendidikan Dan Kebudayaan, 6(3), 264. https:/ / doi.org/10.24246/j.scholaria.2016.v6.i3.p264-272

Dumiyati. (2016). Pendekatan Experiential Learning Dalam Perkuliahan Kewirausahaan Di Perguruan Tinggi. Jurnal Pendidikan Ekonomi Indonesia, 1(1).

Howard Frumkin, Robert Geller, I. Leslie Rubin, and J. N. (2009). Safe and Healthy School Environments. UK: Oxford Universty Pres.

Indonesia, P. R. (2006). Undang-undang Republik Indonesia No 20 Tahun 2003 tentang Sistem Pendidikan Nasional.

Inten, D. N., Permatasari, A. N., Guru, P., Anak, P., Dini, U., Bandung, U. I., ... Bandung, U. I. (2019). Literasi Kesehatan pada Anak Usia Dini melalui Kegiatan Eating Clean. Jurnal Obsesi : Jurnal Pendidikan Anak Usia Dini, 3(2), 366-376. https://doi.org/10.31004/obsesi.v3i2.188

Kemendikbud. (2014). Peraturan Menteri Pendidikan dan Kebudayaan RI, Nomor 137 Tahun 2014 Tentang Standar Nasional Pendidikan Anak Usia Dini.

Kemenkes. (2014). Peraturan Menteri Kesehatan Republik Indonesia Nomor 25 Tahun 2014 Tentang Upaya Kesehatan Anak.

Marmi. (2013). Pengantar Psikologi Kebidanan. Yogyakarta: Pustaka Pelajar.

Putri Abadi, N. Y. W., \& Suparno, S. (2019). Perspektif Orang Tua pada Kesehatan Gigi Anak Usia Dini. Jurnal Obsesi : Jurnal Pendidikan Anak Usia Dini, 3(1), 161. https://doi.org/10.31004/obsesi.v3i1.161

Riyanti, E. (2009). Upaya Peningkatan Kesehatan Gigi dan Mulut Melalui Perubahan Perilaku Anak. Jurnal Majalah Ilmu Kedokteran Gigi, 11(1).

Rohayati, T. (2013). Pengembangan perilaku sosial anak usia dini. Jurnal Cakrawala Dini, 4(2), 131-137. https://doi.org/10.17509/cd.v4i2.10392

Santi, M. Y., \& Sugiyanto, G. (2016). Pendidikan Keselamatan Sejak Usia Dini untuk Mengurangi Tingkat Fatalitas Pejalan Kaki. Jurnal Teknik Sipil, 13(2), 104. https://doi.org/10.24002/jts.v13i2.646

Sari, E. K. (2012). Pengaruh Pendidikan Kesehatan Gosok Gigi Dengan Metode Permainan Simulasi Ular Tangga Terhadap Perubahan Pengetahuan, Sikap, dan Aplikasi Tindakan Gosok Gigi Anak Usia Sekolah di SD Wilayah Paron Ngawi. Indonesian Journal of Community Health Nursing, 1(1), 1-11.

Setyawan, D. (2014). Undang-Undang Republik Indonesia no 35 Tahun 2014 tentang Perubahan atas Undang-undang no 23 Tahun 2002 tentang Perlindungan Anak.

Sharifirad, G. (2011). Comparison of environmental health status in primary schools in different districts of Isfahan city in 2008-2009. Journal of Natural Science, Biology and Madicine, 52(2).

Sholihah, D. A., \& Mahmudi, A. (2015). Keefektifan Experiential Learning Pembelajaran Matematika MTs Materi Bangun Ruang Sisi Datar. Jurnal Riset Pendidikan Matematika, 2(2), 175. https://doi.org/10.21831/jrpm.v2i2.7332

Sulistyowati, R. (2015). Peran Metode Experiential Learning dalam Meningkatkan Kemampuan Komunikasi Mahasiswa. EFISIENSI - KAJIAN ILMU ADMINISTRASI, 7(2). https://doi.org/10.21831/efisiensi.v7i2.3917

Suryaningsih. (2017). Implementasi Metode Experiential Learning Dalam Meningkatkan Kreativitas Mahasiswa PG-PAUD. Jurnal Media Edukasi : Jurnal Ilmu Pendidikan, 1(2).

Suyanto, S. (2012). Pendidikan Karakter untuk Anak Usia Dini. Jurnal Pendidikan Anak, 1(1).

Toosi, A., Rokni, M., Gorji, M. A., Kolaee, S. M. B., Mirmohammadi, S., Yazdani, J., \& Gorji, A. M. (2015). Health, safety and environment conditions in primary schools of Northern Iran. Journal of Natural Science, Biology and Medicine, 6(1), 76. https://doi.org/10.4103/0976-9668.149094 
Trianto. (2007). Mendesain Model Pembelajaran Inovatif-Progresif. Surabaya: Kencana Prenada Media Group.

Wahyuni. (2010). Teori Belajar dan Pembelajaran. Yogyakarta: Ar-Ruzz Media.

Widayati, T. (2018). Pendidikan Keselamatan diri Anak Usia Dini (Studi Kasus di Kelompok Bermain (KB) Gaharu Plus Kutai Kartanegara). JIV-Jurnal Ilmiah Visi, 13(2), 113-122. https:// doi.org/10.21009/JIV.1302.5

Xiong Huang, S. L. (2011). Advances In Computer Science, Environment, Ecoinformatics, And Education, Part IV,. International Conference, CSEE. Wuhan, China.

Yufiarti. (2014). Profesionalitas Guru Pendidikan Anak Usia Dini. Banten: Penerbit universitas Terbuka. 